\title{
The Influence of Auditor Ethics, Auditor Motivation, Locus of Control on Audit Quality: Role of Professional Skepticism
}

\author{
Chriscarol Antami Parluhutan, Ermawati", Shinta Widyastuti \\ Department of Accountancy, Faculty of Economics and Business, Universitas Pembangunan Nasional Veteran Jakarta, Indonesia
}

Received October 20, 2021; Revised December 2, 2021; Accepted December 26, 2021

\section{Cite This Paper in the following Citation Styles}

(a): [1] Chriscarol Antami Parluhutan, Ermawati, Shinta Widyastuti, "The Influence of Auditor Ethics, Auditor Motivation, Locus of Control on Audit Quality: Role of Professional Skepticism," Universal Journal of Accounting and Finance, Vol. 10, No. 1, pp. 267-275, 2022. DOI: 10.13189/ujaf.2022.100127.

(b): Chriscarol Antami Parluhutan, Ermawati, Shinta Widyastuti (2022). The Influence of Auditor Ethics, Auditor Motivation, Locus of Control on Audit Quality: Role of Professional Skepticism. Universal Journal of Accounting and Finance, 10(1), 267-275. DOI: 10.13189/ujaf.2022.100127.

Copyright $\bigcirc 2022$ by authors, all rights reserved. Authors agree that this article remains permanently open access under the terms of the Creative Commons Attribution License 4.0 International License

\begin{abstract}
Good audit quality is needed so that financial statements can be useful for the community as a basis for making decisions. Corruption Eradication Commission (KPK) named Supreme Audit Agency (BPK) members as suspects in the drinking water bribery case because an abnormal value was found in the financial statements and in 2017 the BPK auditor was caught in the practice of purchase and sale opinions on the financial statements of the Ministry of Villages. This can be indicated by the existence of fraud in the audit results which makes the quality of the audit doubtful. This study aims to examine the effect of auditor ethics, auditor motivation, locus of control on audit quality with auditor professional skepticism as an intervening variable. The sample used in this study amounted to 59 samples sourced from auditors Auditorat of State Finances (AKN) V and VI BPK RI with a questionnaire instrument. The analytical technique employed in this study was Structural Equation Modeling (SEM), which was performed with the SmartPLS version 3.0 tool. The findings of this study show that auditor ethics, motivation, and locus of control all have an impact on audit quality, while auditor professional skepticism does not. Furthermore, the relationship between auditor ethics and audit quality cannot be moderated by auditors' professional skepticism.
\end{abstract}

Keywords Auditor Ethics, Auditor Motivation, Locus of Control, Auditor Professional Skepticism, Audit Quality

\section{Introduction}

Audit quality is explained as the auditor's work in the form of reliable work and in accordance with applicable standards [10]. Audit quality is also defined as the characteristics and description of the audit in accordance with standards that reflect the duties and responsibilities of the professional auditor [10]. Research by Ilat et al. [11] stated that audit quality is the possibility that the auditor may encounter irregularities or fraud in the auditee's financial reporting system that refers to applicable standards. Audit quality is very necessary because when the audit quality is high, it will produce financial statements that can be trusted and can be useful for the community as a basis for making decisions.

The Supreme Audit Agency (BPK) is defined by Law No. 15 of 2006 as a state entity entrusted with investigating the management and responsibility of state finances, which includes the Central Government, Regional Governments, other State Institutions, Bank Indonesia, and State-Owned Enterprises (BUMN), Public Service Bodies (BLU), Regional Owned Enterprises (BUMD), and other agencies or bodies involved in state budget management. As regulated by law, BPK has a major role in audits which include financial audits, performance audits and audits with specific objectives. This is carried out in accordance with state financial audit standards, the results of which 
will be given responsibility to the DPR, DPD and DPRD in accordance with their respective authorities. In addition, the auditors of the audit division at BPK RI are the Main Auditorat of State Finances (AKN) I to VII and the Main Auditorate of Investigation.

Reported on the tirto.id [39]. The KPK has named BPK member Rizal Djalil as a suspect in the drinking water bribery case. The financial statements found an unreasonable value of Rp. 18 billion, which was reduced to Rp. 4.2 billion. In 2017, BPK auditors were caught in the practice of buying and selling opinions on the financial statements of the Ministry of Villages for the 2016 fiscal year. The reason is, if BPK accepts bribes from the company where it is assigned, the quality of the audit produced no longer reflects the real condition. Rather it is influenced by certain interests. From these two cases, it is deemed necessary to re-investigate audit quality to explore the factors that affect audit quality.

There have been research that have looked into the factors that influence the audit's quality. Pikirang et al., [1], and Trihapsari and Anisykurlillah [2] states that auditor ethics has an effect on audit quality. Furthermore, the motivational factors of auditors according to Kuntari et al., [3], and Asmara [4] illustrate that audit quality is influenced by auditor motivation. One of the aspects that affects audit quality is the locus of control. Ludmilla et al., [5], and Anugerah et al., [6] states that locus of control has a significant effect. The next factor is the chosen intervening variable, namely the auditor's professional skepticism. Where, according to research by Nugrahaeni et al., [7] and Rifoaffa and Zaldin [8] explain that the use of auditors' professional skepticism affects audit quality. Based on the explanation above, this study aims to determine how government external auditors obtain good audit quality by measuring auditor ethics, auditor motivation, locus of control, and auditor professional skepticism.

\section{Literature Review and hypothesis Development}

\subsection{Audit Quality}

Audit quality is explained as the auditor's work in the form of reliable work and in accordance with applicable standards [9]. Audit quality is also defined as the characteristics and description of the audit in accordance with standards that reflect the duties and responsibilities of the professional auditor [10]. Audit quality, according to Ilat et al., [11], is the likelihood that the auditor would come across irregularities or fraud in the auditee's financial reporting system that refers to applicable standards.

Financial reports that have high quality are used by agencies to be held accountable to the public for the use of state money [12]. To ensure that the financial statements are of high quality, it is necessary to carry out an audit in accordance with the standards [13] Reliable and trustworthy audit quality is a work demand accepted by auditors [26]. This is because users of financial statements in Indonesia expect that budget managers can account for the existing budget for the benefit of the state. Therefore, with the existence of auditors, users of financial statements can ensure that budget management has been going well.

Based on previous research, data collection was carried out using a questionnaire method and using several different indicators. The indicators used in the research of Oktavianto and Suryandari [13], the audit quality indicators used are proposing audit findings carefully and objectively, completing the audit on time, reporting auditee errors, referring to the Professional Standards of Public Accountants (SPAP), alert for decision making, provide recommendations, provide advice on audit reports that are clear and understandable to the auditee, and in accordance with the causes of errors. In contrast to the research of Oktavianto and Suryandari [13], in the research of Kuntari et al. [3] the findings, objective conclusions from the audit results, and recommendations constructive; the accuracy, completeness, and objectivity of the audit report and supported by the results of a report that is convincing, clear, timely, and concise so that the information provided can provide the maximum benefit; a report that must include a related explanation or response from the audited party regarding the results of the examination or audit; matters related to problems that have not been resolved until the end of the audit is listed in the report; the report explains that the recognition of successful achievements is an indicator of good audit quality

\section{Hypothesis Development}

A theory that interprets a person's conduct is known as attribution theory. In practice, it is described how a person's personality determines the cause of his behavior. This idea also refers to how someone describes the reasons of internal or external influences that affect a person's conduct [11]. Personality, personal views, abilities, and motives are examples of internal factors, and external factors, which come from outside, such as the social environment and pressure [15]. Furthermore, this theory, according to Hikmayah and Aswar [14] describe one of the attempts to comprehend the causes of other people's or one's own actions.

Understanding attribution theory, the researchers used the basis of previous research. As done by Akbar et al. [15], by using the research foundation consisting of competence, independence, and motivation. Furthermore, explaining the attribution theory in the explanation of Ilat et al. [11] and Hikmayah and Aswar, [14] regarding internal factors, one of which starts from a person's behavior influencing the behavior of others or personally. Factors that are expected to have an impact on audit quality prompted the creation of the hypothesis. Therefore, the formulated hypothesis is as follows: 
Audit quality can be influenced by auditor ethics, according to attribution theory. Auditors who do not have good ethics and norms can make the community a trust issue towards the auditor profession and vice versa [15]. In compliance with auditing requirements and BPK's code of ethics, preserving norms and ethical norms will sustain professionalism. It is also expected that the auditors will not commit fraud, so that the results given by the audit opinion are in accordance with the financial statements presented [1]. In producing a quality audit, an auditor must understand and understand the existence of responsibilities to the public, clients, fellow auditors, especially respectful behavior [16] Research by Alfiyah et al. [17] found that ethics affects audit quality. These results prove, the higher the auditor's ethical standards, the better the audit will be. This research is confirmed by Pikirang et al. [1], as well as Ningsih and Nadirsyah [16].

\section{$H_{1}$ : Auditor ethics significantly affect audit quality.}

Associated with attribution theory, increasing internal and external auditor factors can also improve the quality of audit results. The auditor's confidence to complete the audit task is one of the factors for the growth of motivation, in addition to client demands and other needs. If the auditor's desires and demands can be addressed, the audit's quality will improve. As a result, high motivation is required to adequately fulfill these jobs and responsibilities [18]. According to Streim [19], one factor that influences the quality of government auditing is motivation. Motivation is required during the audit process since it affects the auditor's performance. According to Herrbach [20], the difference in the auditor's desire to work has an impact on audit quality and is a critical component for auditors to survive in the long term. this research found that the effect of motivation on audit quality increases audit performance. Asmara [4], Kuntari et al.,[3], Rahardjo [21], and Haryana et al., [22] all support these findings.

H2: Auditor motivation significantly affects audit quality.

Locus of Control is explained that a person's perception of the cause of a person's achievement or failure in the activities undertaken [23]. According to Gaol et al. [24], it can be interpreted that a person is directly involved in self-control to produce an attitude or behavior. Locus of Control is also explained as a way of looking at a person to a source who controls good or bad events in the course of his life [5]. In this study, researchers use attribution theory to link internal and external locus of control that can affect audit quality. This locus of control describes auditor behavior as its characteristic to determine audit quality resulting from internal and external factors in motivating their actions [25]. In research, Gaol et al. [24] found that internal locus of control did not negatively affect audit quality behavior. Another opinion was expressed by Ludmilla et al., [5] that audit quality is affected by the locus of control. When compared to auditors with an internal locus of control, those with an external locus of control are more likely to take activities that reduce audit quality [5]. Individuals who adhere to an internal locus of control have superior performance than those who adhere to an external locus of control, according to the features and explanations of locus of control.

\section{H3: Locus of control significantly affects audit quality}

Auditor skepticism refers to the auditor's ethical standards when doing the audit. Auditor skepticism refers to an auditor's attitude of always doubting, questioning, and being critical of existing audit evidence and audit decisions based on his audit expertise [27]. One element that can affect the effectiveness and efficiency of the audit process is auditor skepticism [28]. Attribution theory explains how internal attribution behavior such as attitudes, traits, and character can affect a person's behavior [7]. Auditor skepticism is an attitude taken by the auditor, so attribution theory is chosen to be the theoretical basis for this variable. Several studies have examined whether audit quality can be affected by audit skepticism. In previous research, it was found that audit quality is influenced by auditor skepticism [29]; [30]; [27]. The quality of the audit results improves as the auditor's skepticism grows. Skepticism is important for auditors. Because with this attitude the auditor can be more confident and behave fairly towards the client's financial statements. So that it can produce quality audits [27]. Based on the explanation above, it can be formed hypotheses from this research are:

H4: Auditor professional skepticism significantly affects audit quality.

In the professional skepticism of auditors, stated by Hurtt [31] has several important aspects, namely skepticism is an attitude, skepticism is always channeled through the questioning mind (the mind to always question something related to an event), in the audit process takes place there needs to be a role for skepticism, such skeptics in requiring auditors to assume that client management is dishonest. From the aspects described above, ethics is an important aspect that influences auditor skepticism. This will have an impact on the audit's quality. This supports the findings of Ningsih and Nadirsyah's [16] study, which found that ethics had a significant impact on audit quality.

H5: Auditor ethics significantly affect audit quality through auditor professional skepticism.3.3 Auditor Education.

\section{Methodology}

This study uses quantitative research methods. The goal of this study is to see how intervening variables such auditor ethics, motivation, locus of control, and professional skepticism affect audit quality. Previous research using a variety of statements were used to measure this variable. The measurement scale employs a five-point Likert scale with five measurement interval scales, ranging from 1 (strongly disagree) to 5 (strongly agree) (strongly agree). The measurement of each variable is shown in Table 1. 
Table 1. Measurement Variable

\begin{tabular}{|c|c|c|c|}
\hline variable & Indicator & Statements & source \\
\hline Audit Quality & $\begin{array}{l}\text { Objective audit results with constructive } \\
\text { recommendations, reports can be maximally useful, } \\
\text { reports provide responses from the audited party } \\
\text { regarding the results of the examination, reports explain } \\
\text { problems that have not been resolved, and reports explain } \\
\text { recognition of successful achievements }\end{array}$ & 5 & $\begin{array}{l}\text { Kuntari, Chariri, and } \\
\text { Nurdhiana [3] }\end{array}$ \\
\hline Auditor Ethics & $\begin{array}{l}\text { Accountability by the auditor, in accordance with the } \\
\text { established SAK rules, the error of the report can be } \\
\text { accounted for, improving the report, and considering the } \\
\text { consequences }\end{array}$ & 5 & $\begin{array}{l}\text { Kuntari, Chariri, and } \\
\text { Nurdhiana [3] }\end{array}$ \\
\hline Auditor Motivation & $\begin{array}{l}\text { Policies on service quality, self-evaluation, consistency } \\
\text { of audit results, and being critical in carrying out audit } \\
\text { tasks }\end{array}$ & 4 & $\begin{array}{l}\text { Kuntari, Chariri, and } \\
\text { Nurdhiana [3] }\end{array}$ \\
\hline Locus of control & $\begin{array}{l}\text { Job is what you get out of it, individual planning, work } \\
\text { fits as expected, boss' decisions, strong effort in line with } \\
\text { earned, promotions, appropriate rewards, influence over } \\
\text { boss, good luck getting a job, good luck earning, family } \\
\text { and acquaintances at work, luck in promotion, } \\
\text { relationships in getting a job, relationships in earning } \\
\text { income, luck in being an outstanding employee, and luck } \\
\text { in successfully carrying out tasks }\end{array}$ & 16 & $\begin{array}{c}\text { Gaol, Ghozali, and Fuad } \\
\text { [24] }\end{array}$ \\
\hline $\begin{array}{c}\text { Auditor Professional } \\
\text { Skepticism }\end{array}$ & $\begin{array}{l}\text { Think critically, don't rush in making decisions, develop } \\
\text { knowledge, understand yourself, have confidence, and be } \\
\text { responsible for your own destiny }\end{array}$ & 6 & $\begin{array}{l}\text { Husnianto, Pituringsih, } \\
\text { and Animah [28] }\end{array}$ \\
\hline
\end{tabular}

This research uses a sample of auditors who work in the State Finance Auditorate Units (AKN) V and VI BPK RI according to the sample criteria. The criteria for the sample selected were auditors who had 2 years of experience. This sample can represent the overall quality of audits produced by government external auditors. In this study, the data collection procedure begins with the researcher preparing questions based on indicators to measure and test the research variables. In the second stage, the researcher gave a questionnaire to the auditors of AKN V and VI BPK RI with an online questionnaire via google form. In the second stage, this is done by first signing AKN V and VI BPK RI and submitting an application letter to conduct research in the administration so that it can be followed up to the relevant department. In the next stage, after the respondent has filled out the questionnaire, will automatically enter the researcher's e-mail. Once collected, the results of these respondents will be processed to produce the results of this study.

\section{Result}

The auditors of the AKN V and VI BPK RI units who met the criteria for this study were used as the study's sample. The personnel of BPK RI's Bureau of Public Relations and International Cooperation aided with the distribution of the surveys. This study's data gathering technique yielded 59 responses, a response rate of 65.6 percent.
Table 2. Descriptive Statistics

\begin{tabular}{ccc}
\hline Variable & Mean & Std. Deviation \\
\hline Quality Audit (QA) & 4,40 & 0,23 \\
Auditor Ethics (EA) & 4,44 & 0,14 \\
Auditor Motivation (MA) & 3,68 & 0,84 \\
Locus of Control (LoC) & 3,24 & 0,90 \\
Auditor Professional Skepticism & 4,44 & 0,05 \\
\hline (SPA) & & \\
\hline
\end{tabular}

Table 2 shows that there are a total of 5 questions in the audit quality section, with a mean of 4.40 and a standard deviation of 0.23 . The auditor ethics variable has 5 questions with a mean of 4.44 and a standard deviation of 0.14 . The auditor's motivation variable has a mean of 3.68 and a standard deviation of 0.84 with 4 questions. The next variable is the locus of control. The mean locus of control is 3.24 , the standard deviation is 0.90 with a total of 16 questions. The last variable is the intervening variable in this study, namely the professional skepticism of the auditor. Auditor Professional Skepticism has a mean of 4.44 , a standard deviation of 0.05 and a total of 6 questions. Based on the results of the mean and standard deviation of each variable, there is no significant difference from the respondents' responses. This is because the mean value of each variable is greater than the standard deviation value. These results explain that the smaller the standard deviation describes the homogeneity of the data which is quite high and describes the real data. 
Table 3. Convergent Validity and Reliability

\begin{tabular}{cccc}
\hline variable & Ave & $\begin{array}{c}\text { Composite } \\
\text { Reliability }\end{array}$ & $\begin{array}{c}\text { Cronbach's } \\
\text { Alpha }\end{array}$ \\
\hline EA & 0.702 & 0.917 & 0.880 \\
LoC & 0.544 & 0.875 & 0.844 \\
MA & 0.682 & 0.864 & 0.769 \\
QA & 0.687 & 0.911 & 0.869 \\
SPA & 0.837 & 0.969 & 0.961 \\
\hline
\end{tabular}

The convergent validity was tested using the Average Variance Extracted (AVE) method. The AVE value that should be used is more than 0.50. [32]. Table 3 summarizes the test results, all AVE values in each variable have values above 0.50 . This research illustrates that the variables in this study can be said to be valid. In addition, the value of composite reliability can be said to be reliable or reliable if the value is equal to or greater than 0.7 and Cronbach's alpha is more than 0.6 [32]. The scores for both values for each structure are greater than 0.70 and 0.60 , respectively. These findings show that all of the structures met the requirements for high reliability.

Table 4. Fornell-Larcker Criteria for Discriminant Validity

\begin{tabular}{cccccc}
\hline & EA & QA & LoC & MA & SPA \\
\hline EA & 0.838 & & & & \\
QA & 0.897 & 0.829 & & & \\
LoC & 0.741 & 0.742 & 0.738 & & \\
MA & 0.696 & 0.570 & 0.787 & 0.826 & \\
SPA & 0.843 & 0.725 & 0.844 & 0.823 & 0.915 \\
\hline
\end{tabular}

The discriminant validity test is calculated with indicators that are stated based on the correlation between item scores and construct scores that have been calculated using partial least squares. Correlation can be declared valid when the value is $>0.7$ [32]. As can be seen in table 4, all variables have a value greater than 0.7 . As a result, all constructs on each variable were found to be valid.

Table 5. PLS path algorithm and Bootstrapping

\begin{tabular}{cccc}
\hline Connection & Path Coefficient & T-Value & P-Value \\
\hline EA $\rightarrow$ QA & 0.946 & 13.034 & 0.000 \\
MA $\rightarrow$ QA & -0.210 & 2.251 & 0.025 \\
LoC $\rightarrow$ QA & 0.422 & 3.278 & 0.001 \\
SPA $\rightarrow$ QA & -0.255 & 1.852 & 0.065 \\
EA $\rightarrow$ SPA $\rightarrow$ QA & -0.215 & 1.483 & 0.139 \\
\hline
\end{tabular}

In the meantime, the path coefficient value for examining the association between auditor ethics (EA) and audit quality (QA) is 0.946. As shown in Table 5, the auditor motivation variable (MA) on audit quality (QA) is -0.210 , locus of control (LoC) variable with audit quality (QA) 0.422, auditor professional skepticism variable (SPA) with audit quality variable (QA) -0.255. Lastly is the relationship between auditor ethics variable (EA) on audit quality (QA) through professional skepticism of auditors (SPA) which is worth -0.215 .

Table 5 also shows the outcomes of hypothesis testing utilizing SEM with SmartPLS version 3.0, specifically the PLS method and bootstrapping. The results demonstrate that the audit quality variable is affected by the auditor ethics variable $(\mathrm{EA},=13.034$ and $\mathrm{P}=0.000)$, there is a negative relationship between these two variables. Thus, the lower the auditor's motivation, the higher the quality of the audit produced. The auditor motivation variable (MA, $=2.251$ and $\mathrm{P}=0.025)$, and the locus of control variable $(\mathrm{LoC},=3.278$ and $\mathrm{P}=0.001)$, indicating that $\mathrm{H} 1, \mathrm{H} 2$, and $\mathrm{H} 3$ are acceptable. Meanwhile, the audit quality is unaffected by the auditor's professional skepticism variable (SPA, $=1.852$ and $\mathrm{P}=0.065$ ), indicating that $\mathrm{H} 4$ is rejected. Indirect hypothesis testing on auditor ethics (EA) on audit quality (QA) through auditor professional skepticism (SPA) yielded $(=1.483$ and $P=0.139)$. From these results, it can be stated that indirectly auditor ethics does not have a significant influence on audit quality through the auditor's professional skepticism. So H5 is rejected.

Auditor ethics is defined as a set of principles or morals that have a series of values [16]. Himawati et al. [33] explain that this principle makes every auditor behave professionally and avoid an action that can bring down the profession as an ethical auditor. In producing a good audit quality, it is necessary to hire an auditor who adheres to high auditing standards in terms of ethics and norms [14]. According to the findings, auditor ethics has a considerable impact on audit quality. As a result, H1 is approved. These results are in line with Trihapsari and Anisykurlillah's research [2] conducted at BPK RI Central Java Province, Hikmayah and Aswar's research [14] conducted at BPKP DKI Jakarta Province, Ningsih and Nadirsyah's research [16]. In the studies mentioned above, it is stated that auditor ethics has a significant influence on audit quality. However, these results do not support the research of Himawati et al. [33] conducted at the Inspectorate General of the Ministry of PUPR. In this study it was stated that auditor ethics did not have a significant effect on quality of audit. The findings of this research in line with the attribution theory which explains how the quality of the audit produced by the auditor is influenced by several internal auditor factors, one of which is auditor ethics. Because the ethics of the auditor will indirectly affect the attitude in making decisions chosen by the auditor in accordance with the accounting standards applied.

Motivation is a process to determine the intensity, direction, and desire of a person to take an action to achieve his goals Asmara [4]. Wardana et al. [34] explain that the motivation of an auditor has a strong influence on the results it produces. With motivation, it will increase one's enthusiasm to achieve targets and good audit quality [26]. The t-statistical test is used to describe the link between the auditor's motivation to audit quality. The test results show tcount $>$ ttable of $2.251>2.004$ and the significance value shows $0.025<0.050$. Therefore, the result of this test is 
that the auditor's motivation has a significant effect on audit quality. So, $\mathrm{H} 2$ is accepted. The results of this study are consistent with the research conducted by Kuntari et al. [3] in the Semarang area Public Accountant Firm, the Asmara research [4] conducted at the Jakarta Public Accounting Firm, and Aswar et al. [35] research conducted at the Main Inspectorate of BPK RI. According to these three researches, auditor motivation has a considerable impact on audit quality. However, this result also contradicts the research of Rosnidah et al. [36], [17], and Wardana et al. [34] which proves that auditor motivation has no effect on audit quality. Judging from the path coefficient value, the value of the connection between auditor motivation and audit quality is -0.210 , which means that there is a negative relationship between these two variables. This indicates that the higher the auditor's motivation, the lower the audit quality. It can be seen from the descriptive statistical data of the auditor's motivation on the statement "seriousness in carrying out tasks is often influenced by mood" which gets a low score of 2.47. The findings of this study back up the attribution theory, which states that a person's attitude influences his or her conduct. With the motivation of the auditor raises confidence in the auditor to complete the audit. As a result, high motivation is required to successfully accomplish audit responsibilities.

Locus of control is defined as a person's perspective on the causes or failures of a person in the activities being carried out [23]. According to [25] locus of control describes auditor behavior as a characteristic to determine the quality of the audit that results from internal and external factors in motivating their actions. The relationship between locus of control on audit quality is described by t-statistical test. The results of this test show that tcount $>$ ttable is $3,278>2,004$ and the significance value shows $0.001<0.050$. As a result, the findings of this study show that the locus of control has a considerable impact on audit quality. So, $\mathrm{H} 3$ is accepted. This research is consistent with Ludmilla et al., [5] conducted at BPKP Riau Province, Hariani research [23] conducted at BPK RI. According to the two studies mentioned above, audit quality is affected by locus of control. However, this result contradicts the research by Gaol et al. [24] which was conducted on auditors in Indonesia as many as 240 respondents. In his research, it was found that internal locus of control did not have a negative effect on audit quality behavior. This hypothesis supports the attribution theory, where when an auditor who has a good locus of control, in the sense that the auditor's attitude has been combined with internal factors, will be able to carry out the audit process in accordance with applicable audit procedures. It can be concluded that when the auditor applies a higher locus of control, the level of audit quality produced will increase.

The level of significance between the variables of auditor professional skepticism and audit quality was investigated using a t-statistical test. The test results show that tcount $<$ ttable is $1.852<2.004$ and the significance value shows $0.065>0.050$. So these results illustrate that the auditor's professional skepticism does not have a significant effect on audit quality. Then $\mathrm{H} 4$ is rejected. This result contradicts the research by Kusumawati and Syamsuddin [29] conducted at the South Sulawesi BPK, the research by Nugrahaeni et al. [7] conducted at the Inspectorate General of the Ministry of Environment and Forestry, and the research by Setiyawati et al. [27] conducted at the provincial KAP. DKI Jakarta. These three studies state that auditors' professional skepticism has a significant impact on audit quality. However, the findings of this study support the research of Zuhdi and Faizah [37] conducted at the East Java Representative Office of the BPK. According to the study, auditors' professional skepticism had no substantial impact on audit quality because some auditors were still hesitant to make conclusions in audit results for which the evidence was not clear. In Husnianto et al.'s research [28] conducted at the City/Island Inspectorate of Sumbawa, it was explained that auditors' professional skepticism had no effect on audit quality. Judging from the path coefficient between auditors' professional skepticism and audit quality, it shows a value of -0.210 , which means that there is a negative relationship between these two variables. Thus, the lower the professional skepticism of the auditor, the higher the quality of the audit produced. The fact that this hypothesis was rejected also means that the study's findings do not support the attribution theory. The quality of the audit results is unaffected by theories that analyze a person's behavior, such as professional skepticism. Due to the attitude of skepticism toward the auditor has been considered as a matter of course making it a must in performing audit tasks. If we look at the descriptive statistics of auditors' professional skepticism, it shows a mean result of 4.44 with the meaning in the measurement that the auditor's answers tend to agree and strongly agree. And at a standard deviation of 0.05 , it can be concluded that all respondents' answers are in the homogeneous category and describe the actual data.

Finally, Auditor professional skepticism does not appear to have a major impact on audit quality, according to empirical research. Judging from the results of the mean and standard deviation, the mean amount of professional skepticism of auditors is 4.44 and the standard deviation is 0.05 . This illustrates the standard deviation of providing homogeneous data, proving that it reflects the real data. The mean indicates that the diversity of answers to the questionnaire given tends to agree and strongly agree. When viewed from the descriptive statistics of auditor ethics, the statement "Errors in the report can be accounted for", the mean value is 4.37 . That is, the auditor can be held accountable for improving audit quality. This is felt in the behavior of professional skepticism that is considered normal which makes it a must in completing auditing tasks. The findings of this research state that professional skepticism of auditors does not mediate the effect of 
auditor ethics on audit quality or no mediation. Thus, professional skepticism of auditors cannot intervene or mediate auditor ethics to produce good audit quality. This study also contradicts attribution theory, which explains a person's action in terms of its causes, where auditor ethics in influencing audit quality in a better direction has no effect from auditor professional skepticism. This finding is in line with Darwanto and Kurniasih's [38] investigation at the Inspectorate General of the Ministry of Religion of the Republic of Indonesia. This research states that ethics has no effect on the quality of audit results through professional skepticism. According to him, actions rather than auditor ethics are still often used in making decisions, so that the auditor's skepticism has implications for audit results that are not better.

\section{Conclusions}

After conducting research and a series of hypothesis testing related to the effect of audit ethics, auditor motivation, locus of control on audit quality and auditor professional skepticism as an intervening variable, several conclusions can be drawn, including the following: The ethics of auditors has a substantial impact on audit quality. Therefore, if auditor ethics improves, the quality of audits produced will improve as well. The motivation of auditors has a substantial impact on audit quality. Therefore, if the auditor's motivation decreases, the level of audit quality produced will increase. The audit quality is influenced by the locus of control. Therefore, The higher the audit's locus of control, the higher the audit's quality. Auditor professional skepticism does not have a significant effect on audit quality. Therefore, if the auditor's professional skepticism decreases, the resulting audit quality will increase. Auditor professional skepticism cannot mediate the relationship between auditor ethics and audit quality. So this shows that the auditor's professional skepticism in auditor ethics does not mediate the resulting audit quality. Further research is highly recommended to take advantage of other potential variables in influencing audit quality such as auditor workload, task complexity, discipline, good governance, auditor experience and so on. Then, further researchers are expected to expand the object of research and increase the number of respondents in order to obtain valid and generalizable results. Suggestions that can be given to the auditors of AKN V and VI BPK RI are expected to increase the attitude of professional skepticism of auditors toward the execution of auditing tasks. Then, the auditor must also foster great motivation and enthusiasm so that the audit duties can be appropriately implemented. Furthermore, in order to build public confidence in the audit outcomes, the auditor must increase the locus of control in each audit process.

\section{REFERENCES}

[1] Pikirang, J., Sabijono, H., \& Wokas, H. R. N. "Pengaruh tekanan waktu, independensi dan etika auditor terhadap kualitas audit di kantor Inspektorat kabupaten kepulauan Sangihe. Going Concern," Jurnal Riset Akuntansi, vol, 12, no. 2, pp. 717-732, 2017. https://doi.org/10.32400/gc.12.2. 18034.2017

[2] Trihapsari, D. A., \& Anisykurlillah, I. "Pengaruh etika, independensi, pengalaman audit dan premature sign off terhadap kualitas audit," Accounting Analysis Journal, vol. 5, no. 1, pp. 1-7, 2016. https://doi.org/10.15294/aaj.v5i1.9 756

[3] Kuntari, Y., Chariri, A., \& Nurdhiana, N. "The effect of auditor ethics, auditor experience, audit fees and auditor motivation on audit quality," Sriwijaya International Journal of Dynamic Economics and Business, vol. 1, no. 2, pp. 203-218, 2017. https://doi.org/10.29259/sijdeb.v1i2.1 7

[4] Asmara, R. Y. "Quality of audit: Survey on the external auditor registered," European Journal of Accounting, Auditing and Finance Research, vol. 4, no. 1, pp. 43-76, 2016. Retrieved fromhttps://www.eajournals.org/wp-conte nt/uploads/Effect-of-Competence-and-Motivation-of-Audit ors-of-the-Quality-of-Audit.pdf

[5] Ludmilla, R., Hasan, A., \& Andreas, A. "The influence of time budget pressure, locus of control, and organizational commitment to audit quality and behavior of dysfunctional audit as intervening variable (Empirical study on auditor BPKP Representation of Riau Province)," Jurnal Ekonomi, vol. 26, no. 1, pp. 61-75. 2018. Retrieved from https://je.ejournal.unri.ac.id/index.php/JE/article/view/608 $0 / 5594$

[6] Anugerah, R., Anita, R., Sari, R. N., \& Zenita, R. "External locus of control and reduced audit quality behavior: The mediating effects of auditor performance and organizational commitment," Journal of Economics, Business and Management, vol. 4, no. 5, pp. 353-357, 2016. https://doi.org/10.18178/joebm.2016.4.5.416

[7] Nugrahaeni, S., Samin, S., \& Nopiyanti, A. "Pengaruh skeptisisme profesional auditor, kompetensi, independensi dan kompleksitas audit terhadap kualitas audit," Equity, vol. 21, no. 2, pp. 181, 2018. https://doi.org/10.34209/equ.v21i 2.643

[8] Rifoaffa, H. M., \& Zaldin, A. "Pengaruh kompetensi auditor dan independensi terhadap kualitas audit dengan skeptisme profesional sebagai variabel intervening," Prosiding Seminar Nasional, 2111-2119, 2020. Retrieved fromhttps://www.trijurnal.lemlit.trisakti.ac.id/pakar/article /view/6833

[9] Sukriyah, I., Akram, A., \& Inapty, B. A. "Pengaruh pengalaman kerja, independensi, obyektifitas, integritas dan kompetensi terhadap kualitas hasil pemeriksaan," Simposium Nasional Akuntansi XII, pp. 1-38, 2009. Retrieved fromhttp://blog.umy.ac.id/ervin/files/2012/06/as psia13.pdf

[10] Ramlah, S., Sappewali, B., Ishak, Dwiyanti, E., \& Pontoh, G. T. "The effect of honesty (integrity) auditors, genders and education levels on audit quality," International Conference on Accounting, Management and Economics, 2009. https://doi.org/10.4108/eai.25-10-2019.2295359 
[11] Ilat, V., Saerang, D. P. E., \& Wokas, H. R. N. "Determinant's audit quality of local government in Indonesia," Research Journal of Finance and Accounting, vol. 7, no. 2, pp. 213-224, 2016. Retrieved from https://www.iiste.org/Journals/index.php/RJFA/article/vie $\mathrm{w} / 28546$

[12] Sari, E. N., \& Lestari, S. "Pengaruh kompetensi dan time budget pressure terhadap kualitas audit pada BPK RI perwakilan provinsi Sumatera Utara," Jurnal Riset Akuntansi Dan Keuangan, vol. 6, no. 1, pp. 81-92, 2018. https://doi.org/10.17509/jrak.v6i1.11280

[13] Oktavianto, D. D., \& Suryandari, D. "The factors affecting the audit quality with the understanding on information systems as the moderating variable," Accounting Analysis Journal, vol. 7, no. 3, pp. 168-175, 2018. https://doi.org/10.15294/aaj.v7i3.21008

[14] Hikmayah, N., \& Aswar, K. "The impact of factors on the audit quality in Indonesia: The moderating effect of professional commitments," International Journal of Academic Research in Accounting, Finance and Management Sciences, vol. 9, no. 4, pp. 285-293, 2019. https://doi.org/10.6007/ijarafms/v9-i4/6916

[15] Akbar, F. G., Aswar, K., \& Lastiningsih, N. "Determinants of audit quality in Indonesia supreme audit instituion: A conceptual study," Information Management and Businees Review, vol. 12, no. 2, pp. 38-41, 2020. https://doi.org/10.22610/imbr.v12i2(I).3075

[16] Ningsih, F., \& Nadirsyah, N. "Pengaruh independensi, skeptisisme profesional auditor, penerapan standar audit, dan etika audit terhadap kualitas hasil audit (Studi pada auditor BPK RI perwakilan provinsi Aceh)," Jurnal Ilmiah Mahasiswa Ekonomi Akuntansi, vol. 2, no. 3, pp. 48-58, 2017. Retrievedfromhttp://jim.unsyiah.ac.id/EKA/article/v iew/4467/pdf

[17] Alfiyah, N., Wardayati, S. M., \& Sulistiyo, A. B. "Pengaruh etika, pendidikan, dan pengalaman terhadap kualitas audit dengan profesionalisme sebagai variabel intervening," Jurnal Ekonomi Akuntansi Dan Manajemen, vol. 17, no. 1, pp. 18-34, 2018. https://doi.org/10.19184/jeam.v17i1.2792

[18] Zahmatkesh, S., \& Rezazadeh, J. "The effect of auditor features on audit quality," Tékhne, vol. 15 , no. 2, pp. 79-87, 2017. https://doi.org/10.1016/j.tekhne.2017.09.003

[19] Streim, H. "Agency problems in the legal political system and supreme auditing institutions," European Journal of Law and Economics, vol. 1, no. 3, pp 177-191, 1994. https://doi.org/10.1007/BF01552469

[20] Herrbach, O. "Audit quality, auditor behaviour and the psychological contract," European Accounting Review, vol. 10, no. 4, pp. 787-802, 2001. https://doi.org/10.1080/0963 8180127400

[21] Rahardjo, B. T. "The effect of due professional care and motivation on the quality audit Indonesia," International Journal of Multidisciplinary Research and Development, vol. 4, no. 11, pp 173-182, 2017. www.allsubjectjournal.c om

[22] Haryana, I. K., Yasa, I. B. A., \& Nurhayanti, K. "The effects of task complexity, professional auditor skepticism, and motivation of auditors against quality of audit on public accountants in Bali," Journal of Applied Sciences in Accounting, vol. 2, no. 1, pp. 8-14, 2019.
http://ojs.pnb.ac.id/index.php/JASAFINT

[23] Hariani, S. "Impact of time budget pressure, locus of control, independence, professional skeptisism and audit judgement on audit quality in Indonesian," European Journal of Business and Management, vol. 11, no. 27, pp. 93-100, 2019. https://doi.org/10.7176/EJBM/11-27-10

[24] Gaol, M. B. L., Ghozali, I., \& Fuad, F. "Time budget pressure, auditor locus of control and audit quality reduction behavior," International Journal of Civil Engineering and Technology, vol. 8, no. 12, pp. 268-277, 2017. https://doi.org/10.2139/ssrn.3439844

[25] Parasayu, A., \& Rohman, A. “Analisis faktor-faktor yang mempengaruhi kualitas hasil audit internal (Studi persepsi Aparat Intern Pemerintah kota Surakarta dan kabupaten Boyolali)," Diponegoro Journal of Accounting, vol. 3, no. 2, pp. 1-10. 2014.

[26] Furiady, O., \& Kurnia, R. "The effect of work experiences, competency, motivation, accountability and objectivity towards audit quality," Procedia - Social and Behavioral Sciences, vol. 211, pp. 328-335, 2015. https://doi.org/10.1 016/j.sbspro.2015.11.042

[27] Setiyawati, H., Hidayah, N., Rahmatika, D. N., \& Indriasih, D. "The factors that affect the quality of financial reporting," International Journal of Economics and Management Studies, vol. 7, no. 1, pp. 33-39, 2020. https://doi.org/10.14445/23939125/ijems-v7i1p105

[28] Husnianto, H., Pituringsih, E., \& Animah, A. "Influences of the auditor's professional skepticism, competence, and ethical judgment," International Conference and Call for Papers, pp. 1391-1410, 2017.

[29] Kusumawati, A., \& Syamsuddin, S. "The effect of auditor quality to professional skepticsm and its relationship to audit quality," International Journal of Law and Management, vol. 60, no. 4, pp. 998-1008, 2018. https://doi.org/10.1108/IJLMA-03-2017-0062

[30] Merawati, L. K., \& Ariska, N. L. P. Y. "Pengaruh moral reasoning, skeptisisme profesional auditor, tekanan ketaatan dan self-efficacy terhadap kualitas audit," Jurnal Kumpulan Riset Akuntansi, vol. 10, no. 1, pp. 70-76,2018. https://doi.org/10.22225/kr.10.1.\%25y.70-76

[31] Hurtt, R. K. "Development of a scale to measure professional skepticism," American Accounting Assocuation, vol. 29, no. 1, pp. 149-171, 2010. https://doi.org/10.2308/aud.2010.29.1.149

[32] Hair, J. F., Sarstedt, M., Hopkins, L., \& Kuppelwieser, V. G. "Partial least squares structural equation modeling (PLS-SEM): An emerging tool in business research," European Business Review, vol. 26, no. 2, pp. 106-121, 2014. https://doi.org/10.1108/EBR-10-2013-0128

[33] Himawati, D., Mulatsih, M., \& Putri, F. "Analisis faktor-faktor yang mempengaruhi kualitas audit internal pada Inspektorat Jenderal Kementerian Pekerjaan Umum dan Perumahan Rakyat," Forum Keuangan Dan Bisnis Indonesia, vol. 6, pp. 141-148, 2017.

[34] Wardana, I. M. W., Sapta, I. K. S., \& Landra, I. N. "Competency, independence, motivation, auditor objectives, audit quality, leading policy at Badung Regency Inspectorate," International Journal of Sustainability, Education, and Global Creative Economic, vol. 2, no. 3, pp. 
330-338, 2019. https://doi.org/10.1234/ijsegce.v2i3.124

[35] Aswar, K., Akbar, F. G., Wiguna, M., \& Hariyani, E. "Determinants of audit quality: Role of time budget pressure," Problems and Perspectives in Management, vol. 19, no. 2, pp. 308-319, 2021. https://doi.org/10.21511/ppm.19(2).2021.25

[36] Rosnidah, I., Rawi, R., \& Kamarudin. “Analisis dampak motivasi dan profesionalisme terhadap kualitas audit aparat inspektorat dalam pengawasan keuangan daerah (Studi empiris pada pemerintah kabupaten Cirebon)," Pekbis Jurnal, vol. 3, no. 2, pp. 456-466, 2011. Retrieved from https:/www.neliti.com/publications/8971/analisis-dampak -motivasi-dan-profesionalisme-terhadap-kualitas-audit-apa rat-insp
[37] Zuhdi, R., \& Faizah, F. "Faktor-faktor yang memengaruhi kualitas pemeriksaan (Studi pada auditor BPK perwakilan Jawa Timur)," JAFFA, vol. 1, no. 2, pp. 83-98, 2013. https://doi.org/10.21107/jaffa.v1i2.4004.g2905

[38] Darwanto, D., \& Kurniasih, Y. "Pengaruh orientasi etika, pengalaman dan kompetensi auditor internal terhadap skeptisisme profesional serta dampaknya terhadap kualitas audit (survey pada Inspektorat Jenderal Kementerian Agama RI)," Jurnal Ekonomi Dan Bisnis, vol. 9, no. 1, pp. 73-89, 2018. https://doi.org/10.34308/eqien.v5i2.62

[39] Tirto.id. "Kasus Rizal Djalil dan korupsi-korupsi lain di BPK RI, 2019. (accecced from February, 22, 2021). Retrieved from https://tirto.id/kasus-rizal-djalil-dan-korups i-korupsi-lain-di-bpk-ri-eiQw 